\title{
POLA KUMAN BERDASARKAN PEWARNAAN GRAM PADA TINJA ANAK DENGAN DIARE DI RSUP PROF. DR. R. D. KANDOU MANADO
}

\author{
I Made Dwi Pramana \\ Jeanette I. Ch. Manoppo \\ Rocky Wilar
}

\section{Bagian Ilmu Kesehatan Anak Fakultas Kedokteran Universitas Sam Ratulangi Manado \\ Email: dwiojhan@ymail.com}

Background: Bacterial infection is one of the causes of diarrhea in infants and children. Bacteria are a group of microorganisms belongs to the prokaryotes which are structurally simpler than eukaryotics. There were many examinations used to detect the bacteria caused diarrhea, one of them was microscopic examination of the Gram stain smear. This technique is to determine whether the examination is Gram positive or Gram negative bacteria. Objective: This study aimed to determine the pattern of bacteria by Gram stain in children's feces with diarrhea. Methods: This research used a descriptive designed with cross sectional approach by consecutive sampling from November to December 2013. There were 50 children in this study. Result: The results showed, 29 girls (58\%) and 21 boys (42\%). There were 34 children (68\%) as the largest group that belongs to 1 $<3$ years old. The results of feces microscopic examination showed 29 children (58\%) got contaminated by bacteria. 23 children (46\%) were contaminated with Gram positive and Gram negative bacteria. Gram negative Basil bacteria ware the most common bacteria that found in 23 preparations. Conclusion: Gram-negative bacilli germ were the most common germs that found in children's feces with diarrhea and the numbers of diarrhea on November to December 2013 were increased.

Key words: bacterial pattern, Gram staining, children, diarrhea

Latar belakang: Infeksi bakteri merupakan salah satu penyebab terjadinya diare pada bayi dan anak. Bakteri merupakan mikroorganisme yang termasuk dalam golongan prokariot yang strukturnya lebih sederhana dari eukariot. Banyak pemeriksaan yang dilakukan untuk mendeteksi bakteri penyebab diare, salah satunya dengan pemeriksaan mikroskopis pulasan yaitu pewarnaan Gram yang merupakan salah satu teknik pemeriksaan untuk menentukan apakah termasuk bakteri Gram positif atau bakteri Gram negatif. Tujuan penelitian: Penelitian ini bertujuan unutk mengetahui pola kuman berdasarkan pewarnaan Gram pada tinja anak dengan diare. Metode: Penelitian ini menggunakan desain penelitian deskriptif dengan pendekatan cross sectional yang dilakukan dengan cara consecutive sampling dari bulan November sampai Desember 2013. Sampel penelitian berjumlah 50 anak dan dilakukan pemeriksaan pewarnaan Gram. Hasil penelitian: Hasil penelitian didapatkan, perempuan 29 anak (58\%) dan Laki-laki 21 anak (42\%). Kelompok umur terbanyak $1-<3$ berjumlah 34 anak (64\%). Hasil pemeriksaan mikroskopis feses ditemukan positif bakteri sebanyak 29 anak (58\%). Bakteri Gram positif dan Gram negatif didapatkan berjumlah 23 anak (46\%). Bakteri Basil Gram negatif merupakan bakteri terbanyak yang ditemukan 
yaitu 23 preparat. Kesimpulan: Kuman basil Gram negatif merupakan kuman terbanyak yang ditemukan pada tinja anak dengan diare dan terjadi peningkatan angka kejadian diare pada bulan November - Desember 2013.

Kata kunci : pola kuman, pewarnaan Gram , anak, diare

Infeksi bakteri masih merupakan salah satu penyebab terjadinya diare pada bayi dan anak. Infeksi bakteri pada usus halus lebih sering terjadi di negara berkembang dibandingkan negara maju. Bakteri ini dapat ditemukan hampir di semua tempat yang memungkinkan untuk hidup. Bakteri biasanya ditemukan melekat pada partikel tanah, sisa bahan organik, kulit, gigi, membran epitelium hewan dan manusia. ${ }^{1-3}$ Bakteri merupakan sebuah kelompok mikroorganisme yang termasuk dalam golongan prokariot yang strukturnya lebih sederhana dari eukariot. Bakteri dengan transmisi melalui makanan dapat menyebabkan diare yang menjadi ancaman kesehatan dan bila tidak ditangani lebih lanjut akan menyebabkan dehidrasi bahkan kematian. ${ }^{4-5}$

Di Amerika Serikat lebih dari 5,2 juta kasus diare akibat bakteri terjadi setiap tahunnya. Delapan puluh persen transmisi bakteri melalui makanan dan hanya sebagian kecil bakteri patogen dapat menyebabkan diare melalui orang ke orang. Sekitar 46.000 ribu pasien rawat inap dan 1.500 kematian setiap tahunnya disebabkan oleh bakteri enteropatogen. Keempat bakteri enteropatogen yang paling sering dilaporkan yaitu kampilobakter, salmonella, E.coli dan shigella. Insiden tertinggi infeksi kampilobakter dan salmonella terjadi pada bayi, sedangkan pada anak-anak penyebab tersering yaitu E.Coli. ${ }^{5}$

World Health Organizatian (WHO) melaporkan sekitar 3,5 juta kematian pertahun disebabkan oleh diare, dimana $80 \%$ dari kematian ini terjadi pada anak di bawah umur 5 tahun. ${ }^{6}$ Hasil penelitian Badan Pengelolahan Lingkungan Hidup Daerah (BPLHD) Propinsi DKI Jakarta menunjukkan 80\% sampel air tanah dari 75 kelurahan memiliki kadar E.coli melebihi ambang batas normal. Menurut data Riset Kesehatan Dasar (Riskesdas) tahun 2007 di Provinsi Sulawesi Utara prevalensi diare sebesar 5,4\%. ${ }^{7}$ Survei Demografi dan Kesehatan Indonesia (SDKI) 2007 melaporkan 13,7\% balita mengalami diare dalam waktu dua minggu sebelum survei, 3\% lebih tinggi dari temuan SDKI pada tahun 2002-2003 (11\%). Prevalensi diare tertinggi pada anak umur 12-23 bulan, diikuti 6-11 bulan dan 2345 bulan. Dengan demikian seperti yang diprediksi, diare banyak diderita pada kelompok umur 6-35 bulan karena anak mulai aktif bermain dan berisiko terkena infeksi. Prevalensi diare sedikit lebih tinggi pada anak laki-laki (14,8\%) dibandingkan anak perempuan (12,5\%) dan lebih tinggi pada balita di pedesaan $(14,9 \%)$ dibandingkan perkotaan $(12,0 \%){ }^{8,9}$

Penyebab penyakit diare bersifat multifaktorial. Sebagian besar disebabkan oleh infeksi virus, bakteri dan parasit. Penyebab tersering disebabkan oleh rotavirus, E.coli dan giardia lamblia. Selain itu, faktor-faktor yang dapat meningkatkan resiko infeksi enteropatogen diantaranya umur muda, defisiensi imun, malnutrisi, perjalanan ke daerah endemik, kekurangan ASI, pajanan sanitasi buruk, makan makanan atau air yang terkontaminasi serta tingkat pendidikan ibu. ${ }^{1,10,11}$ 
Data yang didapatkan pada penelitian Manoppo di Bangsal Gastroenterologi Anak Rumah Sakit Prof. Dr. R. D. Kandou Manado mengenai angka kejadian diare akut yaitu sebesar 201 anak dengan diare akut, 123 anak laki-laki dan 78 anak perempuan. ${ }^{12}$

Pemeriksaan mikroskopis pulasan secara langsung merupakan metode yang efisien dan mempermudah untuk mendeteksi bakteri. Metode pewarnaan Gram merupakan salah satu teknik pewarnaan yang bertujuan menentukan apakah bakteri tersebut di dalam kelompok bakteri Gram positif atau bakteri Gram negatif. $^{13,14}$

\section{METODE PENELITIAN}

Penelitian ini menggunakan desain penelitian deskriptif dengan pendekatan cross sectional yang dilaksanakan pada bulan November sampai dengan Desember 2013. Populasi dalam penelitian ini adalah pasien anak yang dirawat di Bagian Ilmu Kesehatan Anak RSUP Prof. Dr. R. D. Kandou Manado. Pengambilan sampel menggunakan metode consecutive sampling. Kriteria inklusi dalam penelitian ini yaitu penderita yang diagnosis dengan diare dan bersedia menjadi responden, sedangkan untuk kriteria eksklusi yaitu dalam masa pengobatan dengan antibiotik dan diare berdarah. Jumlah sampel dalam penelitian ini 50 anak. Variabel dalam penelitian ini diantaranya penderita diare, umur, jenis kelamin dan jenis kuman.

\section{HASIL PENELITIAN}

Tabel 2. Distribusi penderita diare

\begin{tabular}{cccc}
\hline Bulan & $\begin{array}{c}\text { Jumlah anak } \\
\text { penderita diare } \\
\text { (n) }\end{array}$ & $\begin{array}{c}\text { Jumlah seluruh } \\
\text { penderita anak } \\
(\mathbf{n})\end{array}$ & $\begin{array}{c}\text { Incidence } \\
\text { rate } \\
\mathbf{( \% )}\end{array}$ \\
\hline $\begin{array}{c}\text { November - Desember } \\
\mathbf{2 0 1 3}\end{array}$ & 50 & 528 & 9,47 \\
\hline
\end{tabular}

Berdasarkan Tabel 2 dapat dilihat bahwa jumlah penderira diare pada bulan November - Desember tahun 2013 yang memenuhi kriteria sampel berjumlah 50 anak dengan incidence rate 9,47 \% dari 528 penderita anak di RSUP Prof. Dr. R. D. Kandou Manado. 
Tabel 3. Karakteristik sampel menurut jenis kelamin

\begin{tabular}{ccc}
\hline Jenis Kelamin & Jumlah (n) & Persentase (\%) \\
\hline Laki-Laki & 21 & 42 \\
Perempuan & 29 & 58 \\
Total & 50 & 100 \\
\hline
\end{tabular}

Berdasarkan Tabel 3 penderita diare akut lebih banyak pada perempuan dibandingkan laki-laki yaitu masing-masing berjumlah 29 anak (58\%) dan 21 anak (42\%).

Tabel 4. Karakteristik sampel menurut umur

\begin{tabular}{ccc}
\hline Umur (tahun) & Jumlah (n) & Persentase (\%) \\
\hline$<1$ & 6 & 12 \\
$1-<3$ & 34 & 68 \\
$\geq 3-<5$ & 7 & 14 \\
$\geq 5$ & 3 & 6 \\
Total & 50 & 100 \\
\hline
\end{tabular}

Berdasarkan Tabel 4 dapat dilihat bahwa golongan umur yang paling banyak menjadi sampel penelitian yaitu umur $1-<3$ tahun yang berjumlah 34 anak (68\%), kemudian diikuti umur $\geq 3-<5$ tahun yang berjumlah 7 anak (14\%), umur $<1$ tahun yang berjumlah 6 anak (12\%) dan yang paling sedikit adalah umur $\geq 5$ tahun yang berjumlah 3 anak (6\%).

Tabel 5. Karakteristik menurut hasil pemeriksaan mikroskopis feses

\begin{tabular}{ccc}
\hline Hasil & Jumlah (n) & Persentase (\%) \\
\hline Bakteri & 29 & 58 \\
Jamur & 2 & 4 \\
Bakteri + Jamur & 16 & 32 \\
Tidak teridentifikasi & 3 & 6 \\
Total & 50 & 100 \\
\hline
\end{tabular}

Berdasarkan Tabel 5 hasil pemeriksaan mikroskopis feses menunjukkan positif bakteri yang berjumlah 29 anak (58\%), positif jamur yang berjumlah 2 anak (4\%), positif bakteri + jamur yang berjumlah 16 anak (32\%), dan yang tidak teridentifikasi yang berjumlah 3 anak (6\%). 
Tabel 6. Karakteristik hasil pemeriksaan bakteri berdasarkan sifat Gram

\begin{tabular}{ccc}
\hline Hasil & Jumlah (n) & Persentase (\%) \\
\hline Gram + & 14 & 28 \\
Gram - & 10 & 20 \\
Gram + \& Gram - & 23 & 46 \\
Tidak Teridentifikasi & 3 & 6 \\
Total & 50 & 100 \\
\hline
\end{tabular}

Berdasarkan Tabel 6, sifat Gram menunjukkan bakteri Gram positif sebanyak 14 preparat (28\%), bakteri Gram negatif sebanyak 10 preparat (20\%), bakteri Gram positif dan Gram negatif sebanyak 23 preparat (46\%) serta yang tidak teridentifikasi sebanyak 3 preparat (6\%).

Tabel 7. Karakteristik menurut respon bakteri terhadap pewarnaan Gram

\begin{tabular}{ccc}
\hline Hasil & Jumlah (n) & Persentase (\%) \\
\hline Staphylokokus Gram + & 4 & 8 \\
Staphylokokus Gram - & 7 & 14 \\
Streptokokus Gram + & 9 & 18 \\
Streptokokus Gram - & 5 & 10 \\
Basil Gram + & 7 & 14 \\
Basil Gram - & 23 & 46 \\
Kokus Gram + & 13 & 26 \\
Kokus Gram - & 13 & 26 \\
Spiral Gram - & 1 & 2 \\
Candida Gram + & 18 & 36 \\
Total & 100 & 200 \\
\hline
\end{tabular}

Berdasarkan tabel 7 hasil respon bakteri terhadap pewarnaan Gram hasil pemeriksaan yang menunjukan terdapat stafilokokus Gram positif dalam 4 preparat (4\%), stafilokokus Gram negatif dalam 7 preparat (7\%), streptokokus Gram positif dalam 9 preparat (9\%), streptokokus Gram negatif dalam 5 preparat, basil Gram positif dalam 7 preparat (7\%), basil Gram negatif dalam 23 preparat (23\%), kokus Gram positif dalam 13 preparat (13\%), kokus Gram negatif dalam 13 preparat (13\%), spiral Gram negatif dalam 1 preparat (1\%), dan candida Gram positif dalam 18 preparat (18\%).

\section{PEMBAHASAN}

Dari hasil penelitian yang telah dilakukan dengan menggunakan metode consecutive sampling, didapatkan sampel yang memenuhi kriteria selama bulan November - Desember 2013 berjumlah 50 anak, dengan incidence rate sebesar $9,47 \%$. 
Berdasarkan Tabel 3, dapat dilihat jumlah anak perempuan lebih banyak dibandingkan anak laki-laki, masing-masing berjumlah 29 anak (58\%) dan 21 anak (42\%). Hal ini sesuai dengan data Riskesdas 2007 yang menyebutkan bahwa anak perempuan lebih banyak menderita diare. ${ }^{7}$ Penelitian Yusuf pada tahun 2009-2010 di Banda Aceh juga mendapatkan hasil yang sama yaitu prevalensi diare pada balita perempuan sedikit lebih tinggi dibandingkan balita laki-laki. ${ }^{15}$ Penelitian lain menyebutkan bahwa jenis kelamin merupakan faktor yang kurang berpengaruh pada kejadian diare. Menurut Adisasmito, faktor risiko diare pada bayi dan balita di Indonesia menurut jenis kelamin terhadap kejadian diare menunjukkan hubungan yang kurang signifikan. Faktor penyebab lainnya yang dapat menyebabkan diare pada anak seperti usia, jenis kelamin, ASI eksklusif, status gizi, penyakit lain dan pemberian vitamin A. Status gizi merupakan faktor risiko yang paling signifikan dalam menyebabkan diare pada bayi dan balita. ${ }^{8}$

Berdasarkan Tabel 4, didapatkan kelompok umur paling sering yaitu kelompok umur 1 - <3 tahun yang berjumlah 34 anak (68\%) dan kelompok umur terendah berumur $\geq 5$ tahun yaitu berjumlah 3 anak (6\%). Umur 12-23 bulan merupakan puncak terjadinya kejadian diare pada penelitian ini. Hal ini sebanding dengan penelitian yang dilakukan oleh Manoppo dengan golongan umur terbanyak 1 - 3 tahun. ${ }^{12}$ Data SDKI 2007 menyatakan bahwa prevalensi tertinggi pada kelompok umur 6 - 35 bulan karena anak mulai aktif bermain dan berisiko terkena infeksi. ${ }^{9}$ Data Riskesdas 2007 juga menyebutkan bila dilihat per kelompok umur diare tersebar pada semua kelompok umur dengan prevalensi tertinggi terdeteksi pada anak balita. ${ }^{7}$

Berdasarkan Tabel 5, hasil pemeriksaan mikroskopis feses menunjukkan positif bakteri berjumlah 29 anak (58\%), positif jamur berjumlah 2 anak (4\%), dan positif bakteri + jamur berjumlah 16 anak (32\%) serta yang tidak teridentifikasi berjumlah 3 anak (6\%). Dari data yang diperoleh dapat disimpulkan bahwa diare yang disebabkan oleh infeksi bakteri merupakan penyebab terbesar.

Berdasarkan Tabel 6, sifat Gram menunjukkan bakteri Gram positif sebanyak 14 preparat (28\%), bakteri Gram negatif sebanyak 10 preparat (20\%), bakteri Gram positif dan Gram negatif sebanyak 23 preparat (46\%) serta yang tidak teridentifikasi sebanyak 3 preparat (6\%).

Berdasarkan Tabel 7, didapatkan bakteri stafilokokus Gram positif dalam 4 preparat, sedangkan bakteri stafilokokus Gram negatif terdapat dalam 7 preparat. Untuk kelompok bakteri streptokokus didapatkan bakteri streptokokus Gram positif dalam 9 preparat, sedangkan bakteri streptokokus Gram negatif terdapat dalam 5 preparat. Berdasarkan kepustakaan bahwa bakteri stafilokokus dan bakteri streptokokus merupakan Gram positif. Namun, pada penyimpanan tinja yang lama dan bakteri yang mati, stafilokokus dan streptokokus kehilangan sifat Gram positif sehingga terlihat seperti Gram negatif. Keadaan ini dapat terjadi setelah inkubasi semalaman dan pada bakteri yang telah difagositosis. Beberapa streptokokus menguraikan polisakarida kapsular, seperti pneumokokus. Sebagian besar strain menghasilkan kapsul yang terdiri dari asam hialuronat. Kapsul paling mudah terlihat pada sampel yang masih sangat muda, sehingga memberikan pewarnaan Gram positif yang kuat, akibat penuaan banyak sel menjadi Gram 
negatif. ${ }^{16,17}$ Untuk kelompok bakteri kokus hasil pewarnaan menunjukkan hasil yang sama yaitu terdapat dalam 13 preparat, untuk bakteri basil Gram positif terdapat dalam 7 preparat, untuk bakteri basil Gram negatif terdapat dalam 23 preparat, untuk bakteri bentuk spiral terdapat dalam 1 preparat dan jenis candida terdapat dalam 18 preparat. Bakteri yang paling banyak ditemukan dalam penelitian ini ialah basil Gram negatif dan golongan jamur yang paling banyak ditemukan ialah candida. Hal ini sebanding dengan penelitian yang dilakukkan oleh Helena yang menunjukkan bahwa E.coli merupakan kuman golonga basil Gram negatif tersering yang menyebabkan diare. ${ }^{18}$

Keterbatasan dalam penelitian ini ialah peneliti tidak menilai beberapa faktor lain yang mempengaruhi terjadinya diare seperti ASI eksklusif, status gizi, sosial ekonomi dan pendidikan orang tua. Ada beberapa sampel feses dalam penelitian ini yang penyimpanannya melebihi waktu yang seharusnya sehingga hasil yang didapatkan bias serta teknik pewarnaan Gram yang kurang baik.

\section{KESIMPULAN}

Berdasarkan hasil penelitian yang telah dilakukan mengenai pola kuman berdasarkan pewarnaan Gram pada tinja anak dengan diare di RSUP Prof. dr. R. D. Kandou Manado dapat disimpulkan bahwa Kuman basil Gram negatif merupakan kuman terbanyak yang ditemukan pada tinja anak dengan diare dan terjadi peningkatan angka kejadian diare pada bulan November - Desember 2013.

\section{DAFTAR PUSTAKA}

1. Fuazi A, Renaldi K. Penyakit tropic infeksi usus halus. Rani AA, Simadibrata M, Syam AF. Buku Ajar Gastroenterologi. Edisi 1. Jakarta: InternalPublishing; 2011.402-7.

2. Koletzko S, Osterrieder S. Acute Infectious Diarrhea in Children. Dtsch Arztebl Int. 2009;106:538-48.

3. Irianto K. Hubungan ekologi mikroorganisme. Nurhayati N. Mikrobiologi. Jilid 1. Bandung. Yrama Widya.2006.49-54.

4. Bamford K, Gillespie S. Struktur dan klasifikasi bakteri.Astikawati R, Safitri A. At a Glance Mikrobiologi Medis dan Infeksi. Edisi 3. Jakarta:Erlangga.2009.8-9.

5. Herbert L, Dupont MD. Bacterial diarrhea. N Engl J Med 2009;361:1560-9.

6. Simadibrata M. Pendekatan dan penatalaksanaan diare akut. Rani A, Simadibrata M, Syam AF. Buku Ajar Gastroenterologi. Edisi 1. Jakarta Pusat: InternaPublishing; 2011.67.

7. Riset Kesehatan Dasar 2007. Kementerian Kesehatan RI

8. Adisasmito W. Faktor resiko diare pada bayi dan balita di Indonesia. Makalah Kesehatan. 2007;11:1-10.

9. Data dan Informasi Kesehatan 2011. Kementerian Kesehatan RI.

10. Purnamasari H, Santosa B, Puruhita N. Pengaruh suplementasi seng dan probiotik terhadap kejadian diare berulang. Sari Pediatri. 2011;13:96-104. 
11. Pickering LK, Snyder JD. Gastroenteritis. Nelson WE, Behrman RE, Kliegman R, Arvin AM. Nelson Ilmu Kesehatan Anak. Edisi 15. Jakarta: EGC; 2000.889.

12. Manoppo C. Dampak pemberian seng dan probiotik terhadap lama diare akut di Rumah Sakit Prof RD. Kandou Manado. Sari Pediatri. 2010;12:17

13. Chairlan. Bakteriologi. Mahode AA. Pedoman dasar untuk laboratorium kesehatan. Edisi 2. Jakarta: EGC; 2011.192-4.

14. Irianto K. Morfologi dan Pengecatan. Nurhayati N. Mikrobiologi. Jilid 1. Bandung. Yrama Widya.2006.55-72.

15. Yusuf S. Profil diare di ruang rawat inap anak. Sari Pediatri. 2011;13:265-70.

16. Brooks GF, Butel JS, Morse SA. Stafilokokus. Elferia RN, Ramadhani D, Karolina S, Indriyani F, Rianti SSP, Yulia P. Mikrobiologi kedokteran Jawetz, Melnick, \& Adelberg. Edisi 23. Jakarta: EGC.2008.225-32.

17. Brooks GF, Butel JS, Morse SA. Streptokokus. Elferia RN, Ramadhani D, Karolina S, Indriyani F, Rianti SSP, Yulia P. Mikrobiologi kedokteran Jawetz, Melnick, \& Adelberg. Edisi 23. Jakarta: EGC.2008.233-50.

18. Turnip HP. Profil Bayi dan Anak Penderita Diare di Instalasi Rawat Inap RS Cikini. Majalah Kedokteran. 2008:XXVI:1-7. 